\title{
Effect of Cardiac Rehabilitation on Atrial Conductions Following Isolated Coronary Artery Bypass Surgery
}

\author{
Anil Sahin ${ }^{1}$, Omer Tasbulak ${ }^{2}$, Serkan Kahraman ${ }^{2}$, Gokhan Demirci ${ }^{2}$, Hicaz Zencirkiran \\ Agus $^{2}$, Cigdem Altun ${ }^{2}$, Ali Kalkan ${ }^{3}$, and Mehmet Ertürk ${ }^{2}$ \\ ${ }^{1}$ Istinye University \\ ${ }^{2}$ Mehmet Akif Ersoy Thoracic and Cardiovascular Research and Education Hospital \\ ${ }^{3}$ Istanbul Mehmet Akif Ersoy Training and Research Hospital
}

December 26, 2020

\begin{abstract}
Background: Cardiac rehabilitation (CR) is associated with improved clinical outcomes in a broad spectrum of cardiac disease. The beneficial effect of $\mathrm{CR}$ has been proven in patients with ischemic heart diseases. Post-operative atrial fibrillation (AF) and atrial arrhythmias are common complications following coronary artery bypass grafting (CABG) surgery. The aim of this study was to evaluate the effect of $\mathrm{CR}$ on atrial conductions in patients who underwent isolated CABG surgery. Methods: After the exclusion criterion was applied 545 patients were included in the study, retrospectively. One group (Rehab + ) included patients who participated in CR program and the other group (Rehab -) included patients who did not want to or could not be participated in CR program after isolated CABG surgery. ECG parameters of Pmax, Pmin and P wave dispersion (PWD) of both groups were compared. Results: All parameters including heart rate, PR interval, Pmax, Pmin and PWD were significantly changed in rehab $(+)$ group after CABG surgery. There was significant change in rehab $(+)$ group when compared to rehab (-) group in terms of parameters of $\mathrm{Pmax}(\mathrm{P}<0.001)$, Pmin $(\mathrm{P}<0.001)$, $\mathrm{P}$ wave dispersion $(\mathrm{P}<0.001)$. Conclusion: Our findings referred that $\mathrm{CR}$ program significantly improved parameters of atrial conduction including Pmax, Pmin and PWD following isolated CABG surgery. Thereby improvement in atrial conduction by CR program following CABG surgery could reduce atrial arrhythmias.
\end{abstract}

\section{Hosted file}

Manuscript.pdf available at https://authorea.com/users/385301/articles/500788-effect-ofcardiac-rehabilitation-on-atrial-conductions-following-isolated-coronary-artery-bypasssurgery

\section{Hosted file}

Table 1.pdf available at https://authorea.com/users/385301/articles/500788-effect-ofcardiac-rehabilitation-on-atrial-conductions-following-isolated-coronary-artery-bypasssurgery

\section{Hosted file}

Table 2.pdf available at https://authorea.com/users/385301/articles/500788-effect-ofcardiac-rehabilitation-on-atrial-conductions-following-isolated-coronary-artery-bypasssurgery

\section{Hosted file}


Table 3.pdf available at https://authorea.com/users/385301/articles/500788-effect-ofcardiac-rehabilitation-on-atrial-conductions-following-isolated-coronary-artery-bypasssurgery

\section{Hosted file}

Table 4.pdf available at https://authorea.com/users/385301/articles/500788-effect-ofcardiac-rehabilitation-on-atrial-conductions-following-isolated-coronary-artery-bypasssurgery 